\title{
Kajian Kebijakan dan Arah Riset Pasca-Covid-19
}

\author{
Dharendra Wardhana ${ }^{1}$ \\ Kementerian Perencanaan Pembangunan Nasional/Bappenas Republik Indonesia
}

\begin{abstract}
Abstraksi
Riset tentang Covid-19 beserta dampak dan penanganannya sudah berjalan sejak pertama kali wabah ini merebak. Tinjauan kebijakan dalam berbagai disiplin memerlukan pendalaman dan yang terpenting kajian lintas-disiplin sehingga dikotomi kebijakan dapat diminimalisasi. Tulisan sederhana ini berupaya mengidentifikasi ruang dan potensi kajian yang relevan dengan penanganan dan kebijakan pasca-Covid-19 dalam berbagai disiplin dan perspektif. Analisis yang dipergunakan adalah tinjauan literatur terstruktur dengan diawali tinjauan sekilas terhadap tren yang berkembang secara daring. Fitur Google Trends dimanfaatkan untuk mengidentifikasi tren sedangkan situs pencarian ilmiah Google Scholars dipergunakan untuk mengetahui frekuensi karya ilmiah yang diunggah di dunia maya. Piranti lunak VosViewer digunakan untuk mengidentifikasi kluster riset beserta densitasnya. Celah riset masih terbuka lebar dan mengundang para pelaku riset untuk segera berkontribusi menyampaikan gagasan ilmiah beserta solusi konstruktif.
\end{abstract}

Kata Kunci: covid-19; arah kebijakan; arah riset; kajian kebijakan; pandemi covid;

${ }^{1}$ Dharendra Wardhana adalah Kepala Sub Direktorat Perlindungan Sosial, Direktorat Perencanaan Kependudukan dan Perlindungan Sosial Kementerian Perencanaan Pembangunan Nasional/Bappenas. Email: dharendra.wardhana@bappenas.go.id

The Indonesian Journal of Development Planning

Volume IV No. 2 - Juni 2020 


\section{Kajian Kebijakan dan Arah Riset Pasca-Covid-19}

Dharendra Wardhana

\section{Pendahuluan}

Saat artikel ini ditulis, musibah pandemi Covid-19 masih berlangsung dan belum kunjung menemukan titik hentinya. Namun, berbagai analisis, diskusi, dan pemberitaan sudah banyak memberikan telaah atas cakupan (scope), skala, dan magnitude atas persoalan besar ini (untuk telaah lengkap dan rekomendasi lihat Djalante et al., 2020). Berbagai macam proyeksi dan versi analisis para pakar tidak kunjung memberi tanda kapan bencana ini akan berakhir. Banyak pihak skeptis wabah ini akan segera berlalu tetapi lebih banyak yang berharap segera muncul kemajuan besar sehingga kehidupan dapat kembali berjalan normal. Dapat dibayangkan sudah banyak orang merasa jenuh dan tidak sabar menanti berakhirnya fase pembatasan sosial di Indonesia atau karantina (lockdown), isolasi, dan istilah ekuivalen lainnya di negara lain. Kenyataan bahwa rata-rata penemuan vaksin untuk virus baru berkisar antara 12-18 bulan memaksa kita bersiap dengan kondisi yang paling buruk (Chen et al., 2020).

Sekilas tinjauan terhadap pemberitaan seputar Covid-19 di Indonesia didominasi oleh diskursus dan polemik terkait: keterbukaan informasi, strategi komunikasi, trade-off kebijakan ekonomi dan kesehatan, inkonsistensi kebijakan, koordinasi pusat dan daerah. Sedangkan pemberitaan skala global umumnya didominasi pada pencarian vaksin, distribusi global alat kesehatan, dan konsekuensi ekonomi politik atas pilihan kebijakan.

Tulisan ini berupaya mengidentifikasi topik dan tema utama yang potensial untuk digali lebih lanjut serta berpengaruh dalam perumusan kebijakan di tingkat lokal, nasional, maupun global. Sumber utama tulisan ini adalah laman Google Trends dan Google Scholar yang memiliki fitur agregasi untuk merangkum publikasi ilmiah baik yang bersifat peerreviewed maupun sebatas kertas kerja (rujukan riset dengan Google Trends oleh Jun, Yoo and Choi, 2018; Effenberger et al., 2020). Dengan menggunakan pendekatan tinjauan literatur sistematis (systematic literature review) hasil yang didapat dari pencarian beberapa kata kunci diharapkan memberi petunjuk tentang topik potensial untuk riset di masa depan (Bramer, Giustini and Kramer, 2016; Lame, 2019) melalui aplikasi VosViewer untuk mendapatkan visualisasi pemetaan literatur berikut kluster dan densitasnya (Eck and Waltman, 2017). Selain itu, tulisan ini diperkaya oleh artikel di media massa utama (nasional maupun internasional) serta publikasi terawal hingga terkini yang berfokus pada tema seputar Covid-19.

Tinjauan sekilas Google Trends atas tren penggunaan kata kunci 'Covid-19' dan 'ekonomi' dengan cakupan dunia dan Indonesia menunjukkan perbedaan cukup signifikan. Di Indonesia, pengguna (user) cenderung lebih banyak mengakses kata kunci pencairan ekonomi daripada Covid-19 sepanjang waktu. Hanya di kisaran periode pertengahan Maret kata kunci Covid-19 mengalami laju peningkatan pesat. Pada tataran global, pola pencarian warga dunia menunjukkan tren pencarian yang berkebalikan. Sejak awal Maret hingga artikel ini ditulis, kata kunci Covid-19 selalu mendominasi dibandingkan kata kunci ekonomi. Pratinjau sederhana ini memberi sedikit petunjuk bahwa meskipun interest masyarakat Indonesia terhadap Covid-19 mengalami peningkatan, tetapi sesungguhnya di benak mereka lebih menaruh prioritas pada bidang ekonomi. 


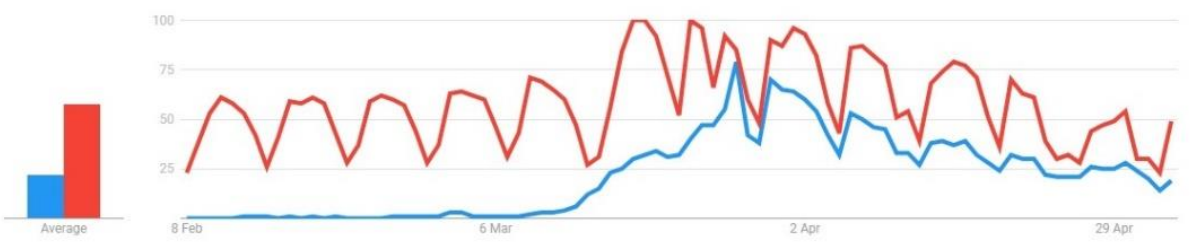

Gambar 1. Pola Pencarian 'Covid-19’ (biru) dan 'ekonomi’ (merah) di Indonesia

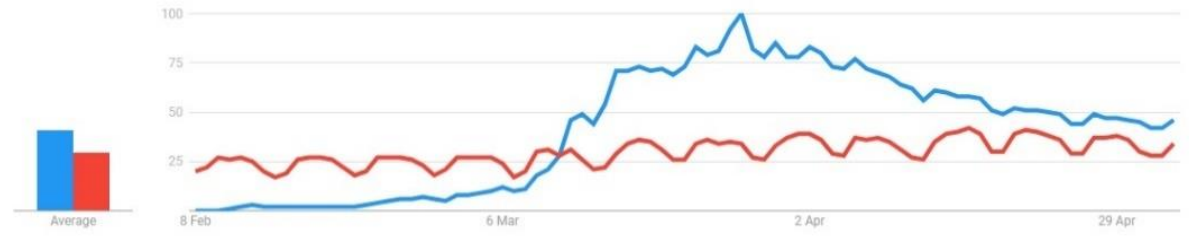

Gambar 2. Pola Pencarian 'Covid-19’ (biru) dan ‘ekonomi’ (merah) di Dunia

Hasil yang berbeda didapat dengan menggunakan variasi kata kunci ‘Covid-19’ dan 'WFH' untuk perbandingan cakupan di Indonesia dan dunia. Pola user dalam melakukan pencarian menggunakan dua kata kunci di Indonesia dan dunia menunjukkan hasil yang mirip. Interest pengguna laman Google menunjukkan dominasi kata kunci Covid-19 daripada WFH (work from home). Sedikit petunjuk mengenai hasil pencarian yang bisa diraba adalah kemungkinan konsep WFH adalah sesuatu yang baru dan belum begitu dekat dengan kehidupan masyarakat sehari-hari.

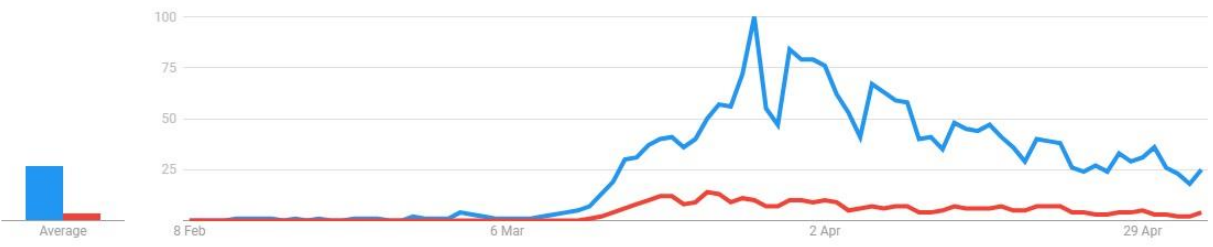

Gambar 3. Pola Pencarian 'Covid-19’ (biru) dan 'WFH' (merah) di Indonesia 


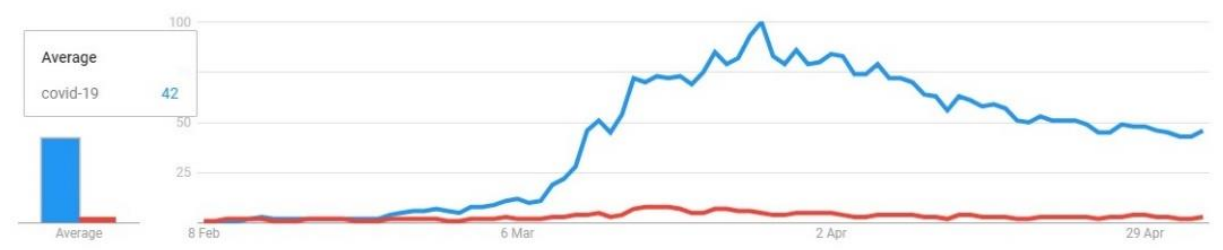

Gambar 4. Pola Pencarian 'Covid-19' (biru) dan 'WFH' (merah) di Dunia

\section{Bencana Kesehatan ke Bencana Ekonomi}

Sudah jamak terdengar sejak wabah merebak tentang teori bencana kesehatan yang mempengaruhi dan menyebabkan bencana ekonomi. Sudah barang tentu, dampak negatif atas dua musibah tersebut akan semakin membesar seiring berjalannya waktu hingga vaksin yang ampuh beredar secara luas (atau menunggu virus tersebut menghilang secara berangsur-angsur). Wabah ini sekaligus semakin mengungkap titik lemah sistem kesehatan di negara-negara berkembang. Guncangan terhadap sistem kesehatan berpengaruh pada prioritas alokasi fiskal. Pengalihan perhatian ke sektor kesehatan berimplikasi pada penurunan prioritas sektor-sektor non-kesehatan yang berpotensi mengubah haluan pembangunan. Mungkin di tahun 2030 nanti, setiap orang akan memaklumi kenapa sebagian besar capaian SDG meleset dari sasaran awal (Hakovirta and Denuwara, 2020). Di masa mendatang, para politisi petahana di berbagai negara akan sibuk membangun dalih force majeur dan berharap permakluman warganya. Sebaliknya kelompok oposisi akan mengungkit kejadian di awal 2020 sebagai kelemahan dan ketidakmampuan petahana sembari menyodorkan gagasan kontrafaktual (yang terlihat lebih baik) dan memakai strategi "what if" sebagai materi kampanye di masa mendatang (Johnson, Pollock and Rauhaus, 2020).

Tabel 1. Proyeksi Pertumbuhan Ekonomi Tahun 2020 (dalam persen)

\begin{tabular}{|c|c|c|c|}
\hline \multirow{2}{*}{ No } & \multirow{2}{*}{ Lembaga } & \multicolumn{2}{|c|}{ Proyeksi } \\
\hline & & Dunia & Indonesia \\
\hline 1 & Asian Development Bank & $\begin{array}{r}-2.3 \text { s.d. }- \\
4.8\end{array}$ & 2.5 \\
\hline 2 & Bank Indonesia & tidak ada & 4.2 s.d. 4.6 \\
\hline 3 & Economist Intelligence Unit & -2.2 & 1.0 \\
\hline 4 & International Monetary Fund & -3.0 & 0.5 \\
\hline 5 & Kementerian Keuangan & tidak ada & 2.3 \\
\hline 6 & Kementerian PPN/Bappenas & tidak ada & 2.2 \\
\hline 7 & LPEM FEB UI & tidak ada & 2.4 s.d. 2.6 \\
\hline 8 & McKinsey & -1.8 & tidak ada \\
\hline 9 & World Bank & tidak ada & -3.5 s.d. \\
\hline
\end{tabular}

Berbagai institusi, lokal maupun internasional, sudah menyajikan proyeksi pertumbuhan ekonomi setelah terdampak Covid-19 (lihat Tabel 1). Sangat menarik untuk dinanti hasil mana yang paling mendekati realitas di masa mendatang sekaligus untuk menguji metodologi dan asumsi yang digunakan. Seperti diduga, proyeksi pertumbuhan ekonomi di tahun 2020 tidak terlalu cerah. Perekonomian global akan berkontraksi di 
kisaran 1,8 hingga 4,8 persen sedangkan ekonomi Indonesia diperkirakan akan tumbuh di kisaran angka dua persen atau bahkan berpotensi menyusut negatif 3,5 persen.

Meskipun gambaran buram tentang dampak negatif cenderung mendominasi, banyak pula yang berupaya menyusun rangkaian cerita positif sebagai hikmah di balik musibah. Sering kita baca bahwa lingkungan terasa semakin bersih karena terbebas dari polusi dan kemacetan yang berkurang drastis selama wabah terjadi. Industri yang selama ini dituding berkontribusi menghasilkan limbah dan polutan turut berhenti seketika. Dunia seakan menikmati rehat sejenak dari eksploitasi penghuninya (Zambrano-Monserrate, Ruano and Sanchez-Alcalde, 2020). Masa depan ideal seolah tergambar di balik musibah. Di sisi lain banyak yang tidak menyadari timbulnya dampak negatif Covid-19 terhadap lingkungan, salah satunya adalah peningkatan sampah plastik (Klemeš et al., 2020).

Namun kondisi lingkungan yang lebih sehat tersebut harus dibayar mahal dengan korban jiwa yang tak tersembuhkan diperparah dengan ambruknya dunia usaha yang berimbas pada pengangguran dan kemiskinan. Pasti sudah terbaca dalam tajuk berita seharihari mengenai kisah miris pemecatan pegawai dan dirumahkannya sejumlah karyawan. Paling menderita khususnya adalah sektor-sektor seperti pariwisata, transportasi, perdagangan. Lebih dahsyat lagi pada perekonomian negara berkembang yang sebagian besar tersusun atas sektor informal atau bazaar economy (diulas dengan baik oleh Charmes, 2019). Kasus kerusuhan di India pasca-penetapan karantina menunjukkan betapa pranata modal sosial yang diharapkan mampu meredam letupan ternyata tidak berdaya (Al Dahdah et al., 2020). Polemik seputar pilihan kebijakan pembatasan dan konsekuensinya terhadap perekonomian diperkirakan mendominasi diskursus bahkan setelah wabah usai (Weible et al., 2020).

Secara intuitif, kajian mendalam dan proyeksi tentang pemulihan ekonomi pascaCovid 19 akan mendominasi diskursus selama beberapa tahun ke depan. Terlebih lagi, dengan preseden krisis moneter Asia 1997-1998 dan krisis finansial global di 2008 menjadikan riset di bidang ekonomi akan senantiasa tampil dalam berbagai publikasi besar. Resesi yang sudah terjadi dan depresi yang sangat mungkin terjadi juga membuat para pakar ekonomi berpikir keras mencari formula yang tepat untuk memulihkan keadaan, apapun ideologi dan mazhab yang dianutnya. Skenario pemulihan dengan berbagai bentuk kurva (V, U, L) sangat tergantung pada seberapa cepat kondisi kesehatan masyarakat dapat dipulihkan sekaligus litmus test atas berbagai kebijakan stimulus ekonomi (Baldwin and di Mauro, 2020). Diskursus yang ada berkaitan dengan pemulihan ekonomi umumnya berkisar pada intervensi fiskal dan relaksasi sektor keuangan.

Pembangunan ekonomi Indonesia yang sudah mencapai jalur menuju status negara berpendapatan menengah-tinggi terancam runtuh dan harus dimulai lagi (restart) seperti kondisi 10-20 tahun lalu (Sumner, Hoy and Ortiz-Juarez, 2020; Suryahadi, Al Izzati and Suryadarma, 2020). Sepintas terlihat sektor yang paling terdampak dan menjadi prioritas untuk dipulihkan seperti pariwisata, transportasi, perdagangan. Kajian yang ditunggu adalah bagaimana mekanisme pemulihan dan periode yang dibutuhkan. 
Tabel 2. Hasil Pencarian Literatur Seputar Covid-19, Ekonomi, Pembatasan Sosial dan Lingkungan (Jumlah Hits)

\begin{tabular}{|c|c|c|}
\hline No. & Kombinasi Kata Kunci & $\begin{array}{l}\text { Google } \\
\text { Scholar }\end{array}$ \\
\hline 1 & $\begin{array}{l}{[\text { Covid-19] OR [COVID-19] OR [coronavirus] OR [virus }} \\
\text { korona }] \text { AND [Indonesia }]\end{array}$ & 350 \\
\hline 2 & $\begin{array}{l}{[\text { Covid-19] OR }[\text { COVID-19] OR }[\text { coronavirus }] \text { OR }[\text { virus }} \\
\text { korona }] \text { AND }[\text { economy }] \text { OR }[\text { ekonomi }] \text { AND }[\text { Indonesia }]\end{array}$ & 39 \\
\hline 3 & $\begin{array}{l}{[\text { Covid-19] OR [COVID-19] OR [coronavirus }] \text { OR [virus }} \\
\text { korona }] \text { AND [economic recovery }] \text { OR [pemulihan ekonomi }] \\
\text { AND [Indonesia }]\end{array}$ & 1 \\
\hline 4 & $\begin{array}{l}{[\text { Covid-19] OR }[\text { COVID-19 }] \text { OR }[\text { coronavirus }] \text { OR }[\text { virus }} \\
\text { korona }] \text { AND }[\text { social distancing }] \text { OR }[\text { lockdown }] \text { OR }[\text { lock } \\
\text { down }] \text { OR }[\text { quarantine }] \text { OR }[\text { pembatasan sosial }] \text { OR } \\
{[\text { karantina }] \text { OR }[\text { PSBB }] \text { OR }[\text { isolasi }] \text { AND }[\text { Indonesia }]}\end{array}$ & 1 \\
\hline 5 & $\begin{array}{l}{[\text { Covid-19] OR [COVID-19] OR [coronavirus }] \text { OR [ virus }} \\
\text { korona }] \text { AND [ environment }] \text { OR }[\text { lingkungan }] \text { AND } \\
\text { [Indonesia }]\end{array}$ & 13 \\
\hline
\end{tabular}

Keterangan: Hasil didapat per 9 Mei 2020

Rekapitulasi hasil pencarian (Tabel 2) menggunakan variasi kombinasi kata kunci seputar Covid-19, ekonomi, dan lingkungan menunjukkan riset dengan lokus Indonesia terlihat masih relatif sedikit. Kombinasi pertama dengan fokus pada Covid-19 dan Indonesia didominasi riset medis yang secara tradisi memang hampir selalu menunjukkan hasil lebih banyak daripada disiplin lainnya. Kombinasi kedua dengan fokus pada Covid-19 dan perekonomian menunjukkan lebih banyak tulisan non-peer reviewed atau grey literature dengan dominasi artikel yang dipublikasikan oleh jurnal terbitan universitas dan institusi akademik. Kombinasi ketiga dan keempat yang berfokus pada kebijakan pemulihan ekonomi dan pembatasan sosial hanya menghasilkan satu hit untuk masing-masing pencarian. Kombinasi kelima mengenai dampak lingkungan menghasilkan angka yang relatif sedikit dibanding pencarian di skala global.

\section{Sistem Kesehatan Pasca-Covid 19}

Sebelum wabah merebak, perhatian khusus terhadap sistem kesehatan sudah sering diulas dalam berbagai jurnal terkemuka dunia. Jurnal ilmiah medis Lancet telah rutin merilis peringkat dan status ketahanan sistem kesehatan negara-negara di dunia ditinjau dari aksesibilitas dan kualitas (publikasi terbaru oleh Fullman et al., 2018). Di masing-masing negara juga telah secara berkala mengadakan penelitian tentang burden of disease (penyakit yang paling sering diderita warganya) serta kesiapan dan kapasitas sarana kesehatan. Telah jamak dipahami bahwa supply sektor kesehatan (fasilitas dan tenaga medis) di Indonesia memang masih kurang jika dibandingkan standar kelayakan negara maju. Namun perkembangannya sebenarnya sudah menuju ke tren yang positif meskipun tantangan besar berikutnya adalah menjamin distribusi akses kesehatan secara lebih merata ke setiap warganya (Agustina et al., 2019).

Wabah Covid-19 menghantam secara tiba-tiba ibarat serangan terorisme bahkan lebih dahsyat. Bahkan negara adidaya seperti Amerika Serikat saja tergagap tak berdaya saat dua menara kembar WTC diserang pada kejadian serangan teror 9/11. Terlihat kembali di masa Covid-19 seperti sekarang, tidak ada jaminan bagi negara dengan ekonomi kuat, 
fasilitas kesehatan maju, status pendidikan warganya tinggi untuk lolos dari wabah mematikan. Sistem layanan kesehatan di negara maju seperti Inggris dengan National Health Services (NHS) juga menghadapi persoalan serius di tengah pandemi dan terancam tidak dapat berfungsi sebagaimana mestinya (Horton, 2020; Willan et al., 2020).

Korelasi yang seharusnya menunjukkan hubungan negatif antara variabel kemajuan di negara maju dengan jumlah korban Covid-19 ternyata tidak terjadi. Kajian mendalam terhadap hal tersebut mungkin sudah dimulai dan saat ini semakin mengerucut ke variabelvariabel seperti: kepemimpinan, transparansi pemerintah, legitimasi, dan perencanaan atau kesiapan.

Tabel 3 Hasil Pencarian Literatur Seputar Covid-19, Sistem Kesehatan, Asuransi Kesehatan, dan Layanan Kesehatan

\begin{tabular}{|c|c|c|}
\hline No. & Kombinasi Kata Kunci & $\begin{array}{l}\text { Google } \\
\text { Scholar }\end{array}$ \\
\hline 1 & $\begin{array}{l}{[\text { Covid-19] OR }[\text { COVID-19] OR }[\text { coronavirus }] \text { OR }[\text { virus }} \\
\text { korona }] \text { AND }[\text { health system }] \text { OR }[\text { sistem kesehatan }] \text { AND } \\
{[\text { Indonesia }]}\end{array}$ & 19 \\
\hline 2 & $\begin{array}{l}{[\text { Covid-19] OR }[\text { COVID-19] OR }[\text { coronavirus }] \text { OR }[\text { virus }} \\
\text { korona }] \text { AND } \text { [health insurance }] \text { OR }[\text { asuransi kesehatan }] \text { AND } \\
\text { [Indonesia }]\end{array}$ & $\mathrm{O}$ \\
\hline 3 & $\begin{array}{l}{[\text { Covid-19] OR }[\text { COVID-19] OR }[\text { coronavirus }] \text { OR }[\text { virus }} \\
\text { korona }] \text { AND } \text { [health care }] \text { OR [layanan kesehatan }] \text { AND } \\
{[\text { Indonesia }]}\end{array}$ & 17 \\
\hline
\end{tabular}

Keterangan: Hasil didapat per 9 Mei 2020

Tabel 3 di atas menunjukkan rekapitulasi pencarian literatur yang menunjukkan kekosongan literatur (paucity) untuk topik riset terkait sistem kesehatan, asuransi kesehatan, dan layanan kesehatan di Indonesia. Hasil tersebut menandakan terbukanya peluang besar untuk kajian lebih mendalam.

\section{Protokol Darurat dan Sistem Perlindungan Sosial}

Paling menentukan dalam menghadapi wabah global ini adalah kesiapan, salah satunya ditandai dengan keberadaan protokol komprehensif darurat (dalam hal ini bidang kesehatan atau social hazard). Jika protokol ini absen, kepanikan serupa dipastikan akan kembali muncul jika terjadi krisis serupa di masa mendatang (Sohrabi et al., 2020). Memang, protokol tersebut baru sebatas menjadi panduan tetapi dalam keadaan kalang-kabut setidaknya kita punya semacam pegangan untuk bertindak lebih jauh dalam menangani krisis. Setidaknya, secara retrospektif kita dapat mengambil pelajaran berharga bahwa strategi "penyangkalan untuk menenangkan masyarakat" tidak lagi efektif. Alih-alih tidak membuat panik, justru reputasi dan kredibilitas Pemerintah menjadi dipertanyakan dalam pengambilan kebijakan. Protokol krisis idealnya mencakup multi-dimensi, tidak hanya spesifik untuk sektor tertentu namun adaptif untuk merespon berbagai guncangan yang berasal dari luar maupun dari dalam.

Krisis hari ini memberikan pelajaran utama sekaligus menunjukkan urgensi perlunya sistem perlindungan sosial yang adaptif. Musykil (jika tidak mustahil) berharap pemerintah atau entitas apapun untuk menyusun pendataan penerima bantuan yang benar-benar tepat seratus persen. Dinamika kesejahteraan dan mobilitas penduduk yang luar biasa membuat rancangan perluasan program hendaknya berpegang pada hal yang paling simpel dan mudah 
dipahami mulai dari penyusun kebijakan paling atas hingga pelaksana paling bawah. Prinsip utama di masa krisis adalah perluasan jumlah penerima (expand) dan peningkatan jumlah manfaat (upscale). Pendataan berbasis means-testing atau indikator proksi lainnya menjadi tidak relevan karena wabah menjangkiti semua kelompok, tidak peduli berstatus miskin atau kaya. Dengan demikian argumen targeting atas dasar efisiensi menjadi tidak relevan dan urgensi untuk universalisasi bantuan semakin meningkat seiring meningkatnya intensitas dampak wabah.

Begitu pula dalam aspek penyaluran bantuan, seharusnya prinsip yang dipegang adalah simplicity daripada menyusun skema baru melibatkan pihak baru pula. Keakuratan data memang menjadi barang mewah namun tidak lebih baik jika kita mencoba menerka alternatif bentuk pendataan lainnya di kala penerapan physical social distancing. Peluang penggunaan dan prospek integrasi data berbasis Nomor Induk Kependudukan belum sepenuhnya siap meskipun sudah sering dipraktikkan dalam berbagai bentuk kerja sama lintas lembaga. Alih-alih memperoleh gambaran pendataan di masa mendatang, seringkali kita temukan penggunaan identitas kependudukan justru menjadi rintangan dalam penyaluran bantuan sosial. Kerumitan langsung terlihat ketika kita ingin menyasar pekerja informal rentan dari daerah luar Jakarta yang mencari nafkah dengan berdomisili sementara di lokasi yang berpindah-pindah. Upaya pencegahan mudik dan pulang kampung dengan pemberian insentif bantuan hidup sementara menjadi terhalang oleh administrasi kependudukan. Asumsi bahwa warga yang tinggal bekerja di suatu wilayah memiliki KTP setempat sudah saatnya ditinggalkan. Persoalan juga sering timbul ketika masa Pemilu saat dimana penduduk penglaju sering terhalang haknya. Masalah seperti ini masih memerlukan kajian yang lebih utuh dan solusi yang lebih praktikal.

Prospek big data dengan melibatkan unicorn seperti Gojek dan Grab serta perusahaan yang mencatat riwayat transaksi konsumennya seringkali terhalang oleh regulasi seputar keamanan privasi dan keengganan terkait rivalitas usaha. Persoalan besar terkait pendataan tentunya dialami oleh negara berpopulasi besar meskipun didukung dengan sistem administrasi kependudukan yang sudah maju. Pergerakan penduduk yang semakin cepat dan era globalisasi saat ini semakin membuat elemen data kependudukan senantiasa berubah (mungkin hanya tanggal lahir dan jenis kelamin saja yang nyaris tidak pernah berubah). Dengan demikian, upaya pemberian bantuan melalui konsep penyasaran seringkali terbentur kendala teknis dan rawan terstigma sebagai inisiatif populis belaka.

Alih-alih mendukung proses penyaluran bantuan, sistem pendataan yang ada pada saat ini cenderung menimbulkan rintangan tambahan. Penduduk tanpa identitas hukum semakin terhalang dalam mengakses bantuan. Prinsip keamanan berlebih know your customer di sektor perbankan menjadi bumerang di masa kritis penyaluran bantuan secara non-tunai melalui rekening. Dengan kondisi sebagian besar masyarakat yang tidak bankable, sangat sulit kiranya berharap penyaluran bantuan berjalan dengan lancar. Daripada menunggu upaya literasi finansial yang memerlukan waktu lebih lama, ada baiknya metode penyaluran konvensional seperti dengan jasa kurir pos dikembangkan kembali. 
Tabel 4. Hasil Pencarian Literatur Seputar Covid-19 dan Sistem Perlindungan Sosial

\begin{tabular}{|c|c|c|}
\hline No. & Kombinasi Kata Kunci & $\begin{array}{l}\text { Google } \\
\text { Scholar }\end{array}$ \\
\hline 1 & $\begin{array}{l}{[\text { Covid-19] OR [COVID-19] OR [coronavirus }] \text { OR [virus }} \\
\text { korona }] \text { AND [ social protection }] \text { OR }[\text { perlindungan sosial }] \\
\text { AND [Indonesia }]\end{array}$ & 8 \\
\hline 2 & $\begin{array}{l}{[\text { Covid-19] OR [COVID-19] OR [coronavirus }] \text { OR [virus }} \\
\text { korona }] \text { AND [ social assistance }] \text { OR [bantuan sosial }] \text { AND } \\
\text { [Indonesia }]\end{array}$ & 25 \\
\hline 3 & $\begin{array}{l}{[\text { Covid-19] OR [COVID-19] OR [coronavirus }] \text { OR [virus }} \\
\text { korona }] \text { AND [targeting assistance }] \text { OR [penyaluran bantuan }] \\
\text { AND [Indonesia }]\end{array}$ & 0 \\
\hline 4 & $\begin{array}{l}{[\text { Covid-19] OR [COVID-19] OR [coronavirus }] \text { OR }[\text { virus }} \\
\text { korona }] \text { AND }[\text { targeting }] \text { OR }[\text { pendataan }] \text { AND }[\text { Indonesia }]\end{array}$ & $\mathrm{O}$ \\
\hline 5 & $\begin{array}{l}{[\text { Covid-19 }] \text { OR }[\text { COVID-19 }] \text { OR }[\text { coronavirus }] \text { OR }[\text { virus }} \\
\text { korona }] \text { AND }[\text { means-testing }] \text { OR }[\text { proxy means testing }] \text { AND } \\
{[\text { Indonesia }]}\end{array}$ & $\mathrm{O}$ \\
\hline
\end{tabular}

Keterangan: Hasil didapat per 9 Mei 2020

Literatur seputar Covid-19 dan sistem perlindungan sosial juga menunjukkan literature gap yang signifikan. Kemungkinan besar karena riset di bidang ini memerlukan sumber data sekunder yang hanya terbit di periode tertentu. Penggunaan data alternatif (misalnya melalui survei Google Forms) masih sangat terbatas. Kebanyakan publikasi berbentuk artikel grey literature (belum melalui proses peer-review) dan mengandaikan persoalan saat ini dengan kejadian sebelumnya (krisis ekonomi 1998 atau 2008).

\section{Transformasi Pola Kerja Menuju WFH}

Kejadian wabah kali ini sekaligus mendorong kajian dan praktik kerja dari rumah (work from home atau disingkat WFH) dan belajar dari rumah (study from home atau disingkat $\mathrm{SFH}$ ) lebih cepat dari yang diimajinasikan sebelumnya. Percepatan implementasi konsep WFH membawa perubahan dan dampak pada proses bisnis dan pola kerja di berbagai bidang. Jelas bahwa tidak seluruh sektor dapat mempraktikkan WFH karena nature bisnisnya, tetapi sektor yang seharusnya berpotensi menerapkan WFH sejak dahulu pun sering mengabaikan peluang pemanfaatannya dengan berbagai alasan. Patut diduga alasan utamanya adalah rintangan teknologi (technology barrier), ketidakpercayaan terhadap bawahan, dan kekhawatiran hilangnya pengendalian (kontrol) atas proses kerja.

Kendala teknologi terdiri atas penguasaan teknis yang seringnya diasosiasikan dengan kecepatan pembelajaran dan usia pengguna. Asumsi yang sering muncul adalah pengguna usia lanjut umumnya terkendala dalam menguasai aspek teknis seperti ini. Kendala lain adalah kelengkapan piranti (umumnya hardware). Kita lihat begitu hari pertama diberlakukan WFH, banyak pekerja mengeluhkan sarana kerja di rumah yang tidak memadai. Pengadaan piranti yang selama ini hanya diprioritaskan bagi pejabat tinggi layak untuk ditinjau ulang mengingat pengerjaan teknis seringnya dilakukan justru oleh pekerja level staf.

Dapat dikatakan bahwa wabah kali ini mampu memaksa implementasi WFH secara penuh. Banyak di antara kita yang akhirnya tersadar bahwa hampir seluruh fungsi pekerjaan dapat dipindahkan dari kantor ke rumah. Namun ternyata masih terdapat fungsi-fungsi yang ternyata belum mampu dikonversi dalam bentuk digital dan virtual seperti tata administrasi 
keuangan dan dokumentasi persuratan. Bentuk pengamanan tanda tangan digital tidak kunjung dikenal dan diterapkan. Terobosan dan kiat mengatasi hal tersebut mungkin tidak bisa menunggu hasil kajian tetapi pendalaman atas perubahan pola kerja di berbagai bidang tentunya menarik untuk dieksplorasi lebih lanjut.

Kementerian PPN/Bappenas yang sudah menginisiasi pola kerja baru dengan konsep integrated digital workspace (IDW) dan pola kerja flexiwork dapat memanfaatkan instrumen yang sudah mulai terbangun. Namun jika ditelisik, pencatatan kinerja di aplikasi Bitrix hanya menunjukkan kisaran angka 3-4 persen setiap hari ini. Begitu pula aplikasi yang diharapkan mendukung pola kerja kolaborasi seperti Office 360 daring dan komputasi awan (cloud computing) ternyata kurang bisa dimanfaatkan dengan berbagai alasan. Sebagian besar kerja tim lintas unit masih mengandalkan pola primitif pengumpulan masukan dengan menerima surel dari berbagai unit secara repetitif sehingga rawan terjadi kesalahan mengingat beban kerja pihak kompilator menjadi sangat besar.

Ini mengindikasikan masih rendahnya pemanfaatan sarana IDW dan mungkin keengganan untuk beradaptasi di lingkungan kerja virtual sepenuhnya. Pola penugasan yang lebih sering dilakukan melalui aplikasi pesan Whatsapp mengindikasikan ketidaknyamanan untuk beranjak dari status quo. Sekaligus juga memberikan sinyal tantangan untuk perubahan rancangan antarmuka (interface) aplikasi kerja. Mungkin sebagian besar kita berharap penugasan dan pengerjaan tugas di aplikasi Bitrix dapat dilakukan semudah mengirim dan menerima pesan di aplikasi Whatsapp.

WFH dan SFH membawa keunggulan seperti penghematan biaya transportasi dan pemanfaatan waktu yang lebih efisien karena terhindar dari macet dan mengurangi paparan polusi udara. Namun konsep penugasan yang tidak mengenal ruang dan waktu berisiko menimbulkan pembebanan yang lebih besar dibanding saat hari kerja biasa. Pegawai diasumsikan dapat lebih banyak mengerjakan tugas karena “dianggap” proses pengerjaannya lebih cepat. Sebaliknya, pegawai yang di masa normal cenderung tidak menerima banyak tugas bahkan mendekati idle, dalam masa WFH ini dapat dipastikan tidak akan lebih produktif dan merasa bingung harus mengerjakan apa.

Tantangan yang dihadapi ketika sudah bekerja di lingkungan virtual adalah menjamin efektivitas kinerja dan melawan kejenuhan. Suasana kerja yang terbatas hanya di rumah dan pembatasan sosial semakin menggerus ketahanan pikiran dan kesehatan mental. Sebelumnya diperkirakan WFH akan membawa manfaat waktu berkualitas bersama keluarga, namun seiring dengan waktu ternyata juga menimbulkan persoalan double burden bekerja dan pengasuhan anak, belum lagi tugas-tugas domestik lainnya yang harus dikerjakan rutin bersaing dengan appointment diskusi virtual yang dalam sehari bisa mencapai 3-4 kali dengan durasi rata-rata 2-3 jam per acara.

Persoalan trust yang belum tuntas dan kendali pimpinan yang makin berkurang tergambarkan pada proses pertemuan virtual. Seringnya pimpinan menegur staf untuk menyalakan kamera muka adalah bentuk pengawasan minimal yang bisa dilakukan. Bahkan jamak ditemui di lembar undangan yang menuliskan pengingat bagi peserta untuk mematuhi dresscode selayaknya bekerja di kantor. Hal ini juga mengindikasikan adanya persoalan netiket dan protokol atau tata tertib pertemuan virtual yang selama ini belum pernah tersusun apalagi menjadi kebiasaan. Pola penugasan yang lebih mudah dilakukan secara lisan harus lebih sering dilakukan secara tertulis dengan respon yang belum tentu instan. Debat yang sudah lama terjadi adalah bagaimana memastikan konsep pengawasan terhadap kedisiplinan pegawai nampaknya masih belum akan berakhir. 
Lebih jauh lagi, dampak penerapan WFH dan SFH menjangkau pada fungsi-fungsi yang berpotensi menjadi redundant atau bahkan idle (tak terpakai) seperti cleaning service, pramubakti (office boy), katering dan peralatan kantor yang mangkrak seperti komputer, printer, mesin faksimili, scanner, dan peralatan lainnya. Sepertinya belum banyak kajian mendalam mengenai fenomena tersebut. Tentunya semua pihak masih berasumsi bahwa proses kerja akan kembali seperti semula dan berpandangan bahwa WFH adalah tidak ideal dan diberlakukan hanya pada masa darurat belaka. Asumsi inilah yang mungkin akan membawa pola business as usual kembali mendominasi pola kerja setelah wabah berlalu.

Bagaimanapun, indikator kinerja yang mengandalkan pada konsep penyerapan anggaran turut berkontribusi pada asumsi tersebut. Pihak yang masih terpaku pada penyerapan anggaran sebagai indikator kinerja dan tidak kunjung menemukan indikator kinerja alternatif akan menemui kesulitan. Anggaran yang dialokasikan setahun sebelumnya menjadi utuh tak tersentuh. Setelah dipotong untuk realokasipun, masih meninggalkan kegelisahan "kapan bisa menyerap anggaran dengan cara seperti biasa?" Keunggulan konsep WFH menjadi tertutup dan seakan hilang dengan pertimbangan-pertimbangan penyerapan dan "aktivasi” fungsi yang tidak terpakai. Belum lagi jika ditelisik bahwa insentif yang hilang selama kurun WFH seperti jamuan, uang saku, uang perjalanan dan lain-lain berpeluang menjadi faktor utama yang mendorong kembalinya mekanisme konvensional. Memang, argumen penyerapan anggaran terkait erat dengan upaya menggerakkan perekonomian yang mati suri (lihat bagian sebelumnya) menjadi relevan dalam upaya pemulihan ekonomi. Ramainya bandara dan menggeliatnya industri MICE (meetings, incentives, conventions, exhibitions) yang didominasi aktivitas pemerintah akan turut berkontribusi dalam proses pemulihan ekonomi.

Dengan semakin lamanya periode WFH, pola belanja tentunya akan bergeser. Diperkirakan item belanja yang sebelumnya tidak teralokasikan seperti paket kuota dan peralatan kerja jarak jauh (komputer dan gawai) akan lebih intensif dibandingkan periode sebelumnya.

Tabel 5 Hasil Pencarian Literatur Seputar Covid-19 dan Work From Home

\begin{tabular}{|c|c|c|}
\hline No. & Kombinasi Kata Kunci & $\begin{array}{l}\text { Google } \\
\text { Scholar }\end{array}$ \\
\hline 1 & $\begin{array}{l}{[\text { Covid-19] OR [COVID-19] OR [coronavirus }] \text { OR [virus }} \\
\text { korona }] \text { AND [work from home }] \text { OR }[\text { bekerja dari rumah }] \text { OR } \\
\text { [kerja dari rumah }] \text { AND }[\text { Indonesia }]\end{array}$ & 30 \\
\hline 2 & $\begin{array}{l}{[\text { Covid-19] OR [COVID-19] OR [coronavirus }] \text { OR }[\text { virus }} \\
\text { korona }] \text { AND }[\text { WFH }] \text { OR }[\text { remote work }] \text { OR }[\text { bekerja jarak } \\
\text { jauh }] \text { AND }[\text { Indonesia }]\end{array}$ & 1 \\
\hline 3 & $\begin{array}{l}{[\text { Covid-19] OR }[\text { COVID-19 }] \text { OR }[\text { coronavirus }] \text { OR }[\text { virus }} \\
\text { korona }] \text { AND }[\text { telecommuting }] \text { AND }[\text { Indonesia }]\end{array}$ & 6 \\
\hline
\end{tabular}

Keterangan: Hasil didapat per 9 Mei 2020

Pencarian literatur seputar Covid-19 dan meningkatnya fenomena bekerja dari rumah (work from home) atau WFH ternyata belum banyak diulas dian dikaji mendalam. Sebagian besar tulisan terpublikasi adalah berbentuk artikel lepas dan sangat jarang yang mengaplikasikan metode riset baku. Patut diduga sebagian besar persoalan manajemen kinerja dan proses bisnis dalam konteks WFH lebih banyak direspon langsung dengan 
perubahan kebijakan secara konkrit tanpa melalui proses uji coba dan menunggu kajian ilmiah.

\section{Menjaga Momentum Kenormalan Baru atau Mengembalikan Kebiasaan Awal}

Kembali ke konvensional atau mengadopsi normalitas baru adalah pilihan yang tergiring atas lingkungan yang sudah melembaga. Lebih penting lagi adalah mengembalikan produktivitas yang sempat berkurang atau menghilang atau menjaga momentum efisiensi selama WFH di era pasca-Covid 19 nantinya. Wabah ini sekaligus menjadi pengingat bahwa karakteristik masa depan yang semakin VUCA (vulnerable, uncertainty, complexity, ambiguity) dan penuh kejutan tak terprediksikan (sering diistilahkan sebagai black swan). Produk lembaga perencanaan seperti rencana jangka panjang, menengah, atau bahkan tahunan berpotensi menjadi tidak relevan hanya karena satu guncangan. Dengan demikian apapun yang berkenaan dengan perencanaan menjadi kurang terlalu relevan untuk menjadi legally and financially binding document.

Sehebat apapun evidence yang kita miliki, nampaknya semakin sulit untuk terbukti akurat dan ditaati dengan berbagai dalih force majeur atau variabel eksternal tak terkontrol seperti perang dagang, pandemik, ketidakstabilan geopolitik, dan faktor besar lainnya. Memang, kita perlu memastikan (get things done) dengan cara melihat progres pencapaian setiap komponen dengan membandingkan posisi awal (baseline) dengan sasaran akhir (biasanya diterjemahkan dari visi politik pimpinan). Tetapi karakter VUCA tetap harus melekat dan diantisipasi dalam penyusunan dokumen perencanaan serta tidak bersifat zakelijk.

Bukan berarti lantas dokumen perencanaan seperti RPJPN, RPJMN, RKP lalu kita tinggalkan begitu saja, tetapi mungkin konten dan struktur yang perlu kita sesuaikan sehingga lebih adapt ke VUCA. Selain itu, Bappenas juga diharapkan memiliki nilai (values) baru (misalnya sebagai pemampu atau enabler) dan lebih konkrit menerjemahkan cita-cita bersama.

Tabel 6. Hasil Pencarian Literatur Seputar Covid-19 dan Perencanaan

\begin{tabular}{|c|c|c|}
\hline No. & Kombinasi Kata Kunci & $\begin{array}{l}\text { Google } \\
\text { Scholar }\end{array}$ \\
\hline 1 & $\begin{array}{l}{[\text { Covid-19] OR [COVID-19] OR [coronavirus }] \text { OR [virus }} \\
\text { korona }] \text { AND [planning] OR [perencanaan }] \text { AND }[\text { Indonesia }]\end{array}$ & 12 \\
\hline 2 & $\begin{array}{l}{[\text { Covid-19] OR [COVID-19] OR [coronavirus }] \text { OR }[\text { virus }} \\
\text { korona }] \text { AND }[\text { projection }] \text { OR }[\text { proyeksi }] \text { AND }[\text { Indonesia }]\end{array}$ & 2 \\
\hline 3 & $\begin{array}{l}{[\text { Covid-19] OR }[\text { COVID-19] OR }[\text { coronavirus }] \text { OR }[\text { virus }} \\
\text { korona }] \text { AND }[\text { vulnerability }] \text { OR }[\text { uncertainty }] \text { OR } \\
{[\text { complexity }] \text { OR }[\text { ambiguity }] \text { AND }[\text { Indonesia }]}\end{array}$ & 3 \\
\hline
\end{tabular}

Keterangan: Hasil didapat per 9 Mei 2020

Hasil pencairan sekilas menunjukkan belum banyak literatur yang menelaah tentang karakteristik masa depan yang penuh ketidakpastian dengan pola perencanaan pembangunan, khususnya di Indonesia.

\section{Kecepatan Perumusan Kebijakan dan Jaminan Kualitas Kajian}

Telaah dan oto-kritik atas penanganan bencana semakin mengarah pada pentingnya kebijakan berbasis bukti (evidence) sekaligus tantangan bagi lembaga pemikir (think tank) untuk penyusunan kajian kebijakan dan rekomendasi dalam jendela waktu yang sempit. 
Telah banyak diskusi, kajian, analisis dan opini yang dikerjakan namun tantangan besar berikutnya adalah menilai "seberapa berkualitas" hasil-hasil tersebut. Tidak ada pihak yang terbebas dari kelemahan atas hasil kerja pikir. Momen seperti ini juga menjadi kancah pembuktian lembaga riset dan tangki pemikir untuk tidak hanya sekadar menjadi institusi menara gading yang hanya mampu melempar wacana nir-solusi.

Terlalu banyak diskusi yang berujung pada pelontaran kritik yang terkadang tidak proporsional. Dengan menganggap dirinya lebih unggul bermodal kredensial akademik atau publikasi di jurnal papan atas, lembaga pemikir tersebut sering melupakan konteks dan kondisi exsisting tata pemerintahan dan pola pengambilan kebijakan. Kecenderungan mengasumsikan segalanya taken for granted dan berada pada kondisi ideal sering membuat mereka lebih banyak menyampaikan keluhan daripada mencari terobosan jalan keluar yang lebih masuk akal. Sudah saatnya mengonversi perasaan frustrasi menjadi energi positif untuk membuat solusi yang lebih konstruktif.

Lebih lanjut, selama ini kajian yang dianggap evidence-based atau teknokratik seharusnya melewati fase pengujian dan praktik terbatas (pilot) untuk mendapatkan penilaian yang lebih objektif. Khususnya di masa-masa kritis yang memerlukan masukan kebijakan dalam tempo lebih cepat dari kondisi normal. Argumen bahwa segala hasil kerja yang diproduksi oleh lembaga pemikir perlu ditinjau dan tidak langsung dapat diterima sebagai satu-satunya hasil yang teknokratik, objektif, dan kredibel. Meskipun industri pengetahuan dan ekosistem riset belum terbangun benar, pelaku industri riset sudah mulai bertambah dengan berbagai skala dan ideologi yang bervariasi. Sudah saatnya kompetisi ide dan gagasan diberikan gelanggang untuk memperoleh masukan yang terbaik.

Tabel 7 Hasil Pencarian Literatur Seputar Covid-19 dan Perumusan Kebijakan

\begin{tabular}{|c|c|c|}
\hline No. & Kombinasi Kata Kunci & Google \\
\hline 1 & $\begin{array}{l}\text { Covid-19] OR [COVID-19] OR [coronavirus }] \text { OR [virus } \\
\text { korona }] \text { AND [policymaking }] \text { OR [perumusan kebijakan }] \text { AND } \\
\text { [Indonesia }]\end{array}$ & 1 \\
\hline 2 & $\begin{array}{l}{[\text { Covid-19] OR [COVID-19] OR [coronavirus }] \text { OR }[\text { virus }} \\
\text { korona }] \text { AND }[\text { think tank }] \text { OR }[\text { lembaga penelitian }] \text { AND } \\
\text { [Indonesia }]\end{array}$ & 2 \\
\hline
\end{tabular}

Keterangan: Hasil didapat per 9 Mei 2020

Pencarian literatur seputar proses perumusan kebijakan dengan menggunakan kata kunci yang berkenaan ternyata hanya menghasilkan sangat sedikit karya literatur dan kemungkinan besar tidak relevan dengan topik spesifik yang dibahas pada bagian ini. Kekosongan ini perlu segera diisi dengan kajian komprehensif yang dapat merumuskan suatu mekanisme untuk menentukan kajian berkualitas yang dapat diadopsi sebagai bahan perumusan kebijakan. Beberapa institusi sudah memulai kiat untuk meningkatkan kecepatan perumusan kajian ilmiah, misalnya Centre for Economic Policy Research (CEPR) yang membuat call for paper untuk kajian singkat (paper maksimal 5.000 kata) dengan masa telaah hanya dalam kurun 48 jam sebelum dinyatakan layak dimuat atau ditolak.

\section{Topik Penelitian Potensial}

Untuk meraba topik atau tema yang potensial diperdalam di masa mendatang, tulisan ini mendasarkan pada metode tinjauan terstruktur sistematis sederhana dengan tujuan utama untuk menghasilkan sebuah ringkasan terkait berbagai tema seputar Covid-19 dan 
kaitannya dengan bagian yang sudah diulas sebelumnya. Metode review terstruktur yang digunakan berbasis pada tiga kriteria untuk menjaring artikel-artikel yang memuat topik relevan yang difokuskan pada konteks Indonesia dan mencakup tataran global yang masih berkaitan dengan Indonesia.

Kriteria pertama adalah pemilihan kata kunci yang tepat dan relevan untuk mencari kumpulan artikel dalam basis data elektronik. Variasi kata kunci seperti 'Covid-19' atau 'COVID-19' dan variasi minor lainnya dengan tambahan ketentuan khusus pada kata tersebut dilekatkan untuk menyaring setiap artikel, misalnya: 'economic recovery', 'emergency protocol', 'social protection', 'targeting benefits', 'work from home' dan kombinasi kata kunci lainnya. Hal tersebut dilakukan untuk memastikan bahwa artikel yang diperoleh benar-benar sesuai dengan tema yang diangkat dalam kajian ini. Kriteria kedua adalah tipe artikel yang dipilih untuk proses analisis data yakni hanya menggunakan artikel yang diterbitkan oleh jurnal internasional peer-reviewed berbahasa Inggris untuk jurnal ilmiah yang sudah terindeks di portal basis data terkemuka (di antaranya adalah Crossref, Scopus, Web of Science, Medlink) dan ditambah pilihan arbitrary publikasi di kanal media besar di beberapa negara. Kajian dibatasi dengan periode awal Januari 2020 hingga bulan Mei 2020. Kriteria ketiga yang digunakan adalah lintas bidang atau multi-disiplin untuk membuka peluang mendapatkan artikel-artikel di luar bidang sains dan sosial untuk meningkatkan keragaman perspektif.

Analisis pemetaan literatur memakai aplikasi Vos Viewer menunjukkan pengelompokan genre dan tema dalam empat kluster (Gambar 5). Keterhubungan antar kluster juga terlihat dari skema yang dihasilkan. Terlihat bahwa kluster 'pandemi' (warna merah) terlihat berada di ujung paling kiri dan hanya terhubung dengan kluster 'model' (warna biru). Kluster model memiliki koneksi tidak hanya dengan kluster pandemik tetapi juga kluster 'scenario' (warna hijau muda). Di ujung kanan (warna hijau tua) terdapat kluster 'poverty' yang hanya terhubung dengan kluster 'scenario'.

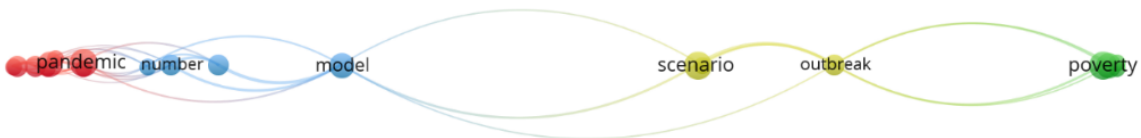

急 Vosviewer

Gambar 5. Diagram Pemetaan Literatur Hasil Pencarian Awal

Gambar 6 menunjukkan "mata rantai putus" dalam hal densitas riset yakni di antara kluster 'pandemi' (di ujung kiri) dengan kluster poverty yang berada di ujung kanan. Kluster di bagian tengah yang masih menunjukkan celah penelitian berada pada ranah topik dengan kata kunci 'model' dan 'scenario'. Dilihat dari ukuran densitasnya, kluster 'pandemi' menunjukkan ukuran terbesar diikuti oleh kluster 'poverty' yang tidak terhubung langsung. Sedangkan kluster 'model' menunjukkan ukuran terkecil. Kemungkinan besar disebabkan 
oleh minimnya data tersedia atau banyaknya versi data yang membuat pelaku riset menjadi ragu terhadap akurasi dan reliabilitas data yang akan digunakan.

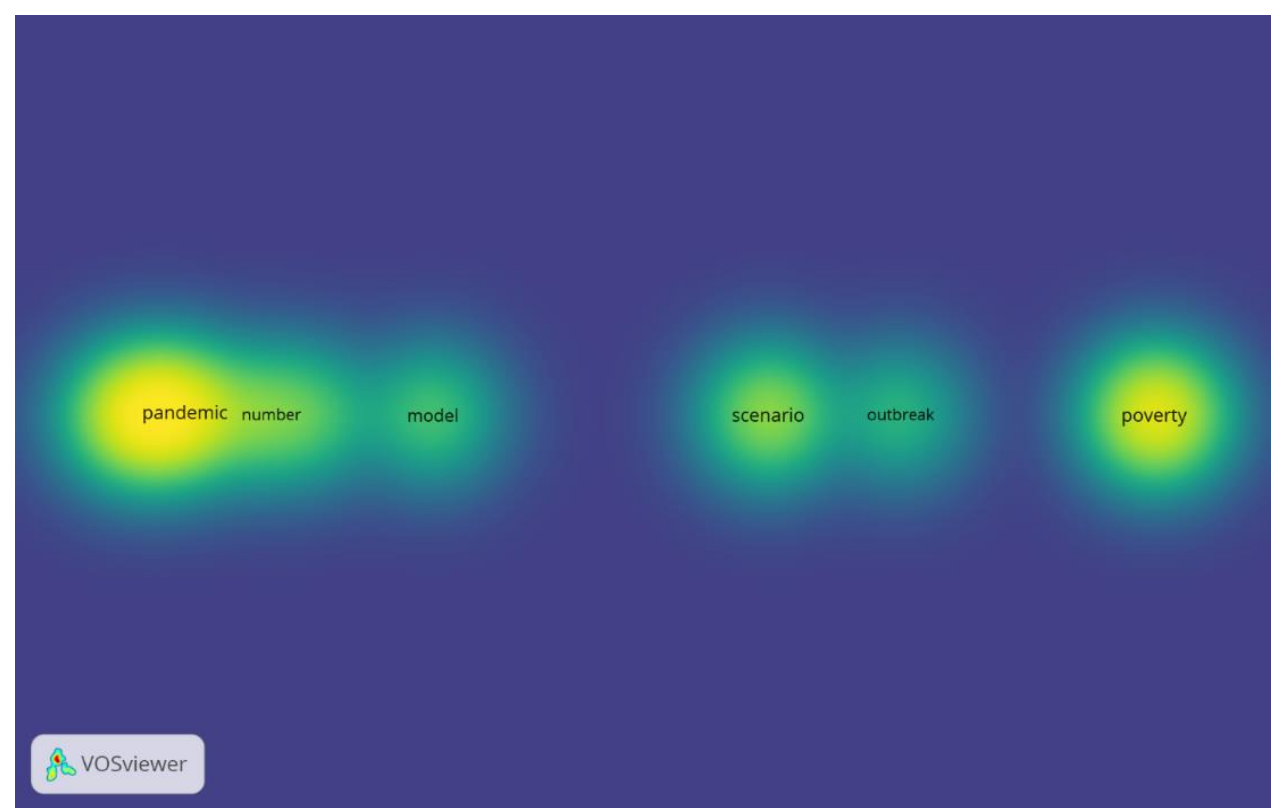

Gambar 6. Visualisasi Densitas Kluster Hasil Pencarian

Gambar 7 merupakan penjelasan dari ilustrasi sebelumnya dengan fokus observasi pada kluster 'pandemi' yang berada di ujung kiri dan memiliki ukuran densitas terbesar. Terliat bahwa dalam kluster ini terdapat beberapa kata kunci yang menjadi inti seperti katakata kunci: 'government', 'recommendation', dan 'medical supply'. Patut diduga, kata kunci sentral ini lebih kerap muncul di berbagai kajian dalam konteks perumusan kebijakan bagi pemerintah di sektor yang paling terkait dalam kluster ini yaitu: kesehatan.

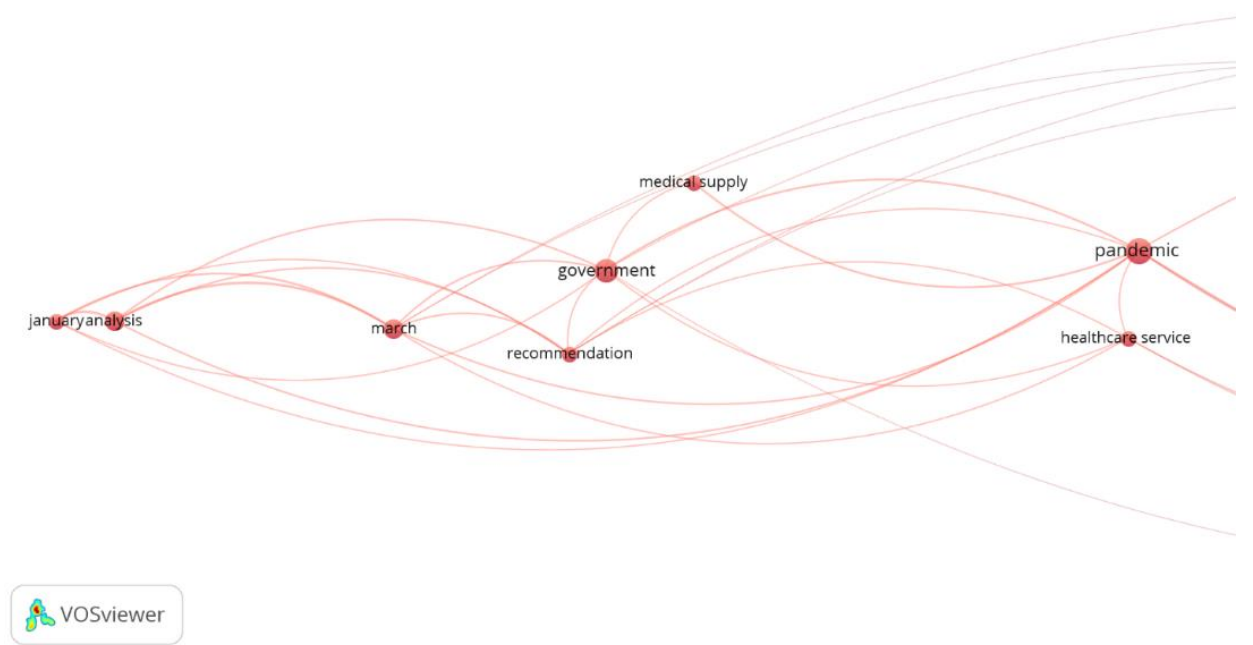

Gambar 7. Perbesaran Visualisasi Kluster Hasil Pencarian 


\section{Kesimpulan dan Tindak Lanjut Peluang Riset}

Data dianalisis dengan teknik bibliometrik berdasarkan pada protokol analisis bibliometrik dari Eck dan Waltman (2017) yang terdiri atas: a) menentukan kata kunci pencarian; b) memperoleh hasil awal pencarian; c) memperbaiki hasil pencarian; d) mengumpulkan data awal; dan e) menganalisis data. Teknik bibliometrik digunakan untuk merepresentasikan sisi kuantitatif hasil-hasil penelitian yang berbentuk artikel jurnal, buku, atau jenis-jenis komunikasi tertulis lainnya. Selanjutnya, untuk memperoleh hasil analisis yang lebih komprehensif maka dilakukan identifikasi dan pengelompokan konten artikel berdasarkan objektif, kerangka teori, dan metodologi. Tahapan analisis akan dijelaskan pada bagian berikut.

Dengan melihat sekilas hasil pencarian menggunakan Google Scholar di bagian sebelumnya sudah terlihat masih banyak peluang kajian yang dapat dikerjakan dengan berbagai metode dan sudut pandang analisis. Masih banyak persoalan yang berada di seputaran kita (sebelum, ketika, dan setelah) masa Covid-19 yang belum terpecahkan. Mungkin sebagian tidak memerlukan kajian mendalam tetapi lebih baik lagi jika proses pengambilan kebijakan mengikutsertakan evidence yang kredibel dan berorientasi pada solusi konkrit. Sedangkan hasil pemetaan literatur dengan VosViewer menunjukkan urgensi riset pada kluster-kluster yang belum terhubung satu sama lain. Ilustrasi densitas juga memperlihatkan fokus riset pada bidang-bidang yang saat ini menjadi perhatian utama para pelaku di kancah epistemik dan akademik.

\section{Daftar Pustaka}

Agustina, R. et al. (2019) 'Universal health coverage in Indonesia: concept, progress, and challenges', The Lancet, 393(10166), pp. 75-102. doi: 10.1016/So140-6736(18)316477 .

Baldwin, R. and di Mauro, B. W. (2020) Economics in the Time of COVID-19. London: CEPR Press. Available at: https://voxeu.org/content/economics-time-covid-19.

Bramer, W. M., Giustini, D. and Kramer, B. M. R. (2016) 'Comparing the coverage, recall, and precision of searches for 120 systematic reviews in Embase, MEDLINE, and Google Scholar: a prospective study', Systematic Reviews, 5(1), p. 39. doi: 10.1186/s13643-016-0215-7.

Charmes, J. (2019) 'A Brief History of 50 Years of Conceptualisation and Measurement of the Informal Economy', in Charmes, J. (ed.) Dimensions of Resilience in Developing Countries: Informality, Solidarities and Carework. Cham, Switzerland: Springer Nature, pp. 13-36. doi: 10.1007/978-3-030-04076-5.

Chen, W.-H. et al. (2020) 'The SARS-CoV-2 Vaccine Pipeline: an Overview', Current Tropical Medicine Reports. doi: 10.1007/s40475-020-00201-6.

Al Dahdah, M. et al. (2020) 'The Covid-19 Crisis in India: Chronicle of A Tragedy Foretold'. Paris: College de France. Available at: https://booksandideas.net/The-Covid-19Crisis-in-India.html.

Djalante, R. et al. (2020) 'Review and analysis of current responses to COVID-19 in Indonesia: Period of January to March 2020', Progress in Disaster Science, 6, p. 100091. doi: 10.1016/j.pdisas.2020.100091.

Eck, N. J. and Waltman, L. (2017) 'Citation-based clustering of publications using CitNetExplorer and VOSviewer', Scientometrics. Springer Netherlands, 111(2), pp. 1053-1070. doi: 10.1007/s 11 192-017-2300-7.

Effenberger, M. et al. (2020) 'Association of the COVID-19 pandemi with Internet Search Volumes: A Google TrendsTM Analysis', International Journal of Infectious Diseases. 
International Society for Infectious Diseases, 95, pp. 192-197. doi: 10.1016/j.ijid.2020.04.033.

Fullman, N. et al. (2018) Measuring performance on the Healthcare Access and Quality Index for 195 countries and territories and selected subnational locations: a systematic analysis from the Global Burden of Disease Study 2016', The Lancet. Elsevier, 391(10136), pp. 2236-2271. doi: 10.1016/So140-6736(18)30994-2.

Hakovirta, M. and Denuwara, N. (2020) 'How COVID-19 Redefines the Concept of Sustainability', Sustainability, 12(9). doi: 10.3390/su12093727.

Horton, R. (2020) 'Offline: COVID-19 and the NHS-“a national scandal”, Lancet (London, England). 2020/03/26. Elsevier Ltd., 395(10229), p. 1022. doi: 10.1016/So1406736(20)30727-3.

Johnson, A. F., Pollock, W. and Rauhaus, B. (2020) 'Mass casualty event scenarios and political shifts: 2020 election outcomes and the U.S. COVID-19 pandemi', Administrative Theory and Praxis. Routledge, O(0), pp. 1-16. doi: 10.1080/10841806.2020.1752978.

Jun, S. P., Yoo, H. S. and Choi, S. (2018) 'Ten years of research change using Google Trends: From the perspective of big data utilizations and applications', Technological Forecasting and Social Change. Elsevier, 130(November 2017), pp. 69-87. doi: 10.1016/j.techfore.2017.11.009.

Klemeš, J. J. et al. (2020) 'Minimising the present and future plastic waste, energy and environmental footprints related to COVID-19', Renewable and Sustainable Energy Reviews, 127(April). doi: 10.1016/j.rser.2020.109883.

Lame, G. (2019) 'Systematic Literature Reviews: An Introduction’, Proceedings of the Design Society: International Conference on Engineering Design. Cambridge University Press, 1(1), pp. 1633-1642. doi: 10.1017/dsi.2019.169.

Sohrabi, C. et al. (2020) 'World Health Organization declares global emergency: A review of the 2019 novel coronavirus (COVID-19)', International Journal of Surgery. Elsevier, 76(February), pp. 71-76. doi: 10.1016/j.ijsu.2020.02.034.

Sumner, A., Hoy, C. and Ortiz-Juarez, E. (2020) Estimates of the impact of COVID-19 on global poverty. 2020/43. Helsinki. Available at: https://www.wider.unu.edu/publication/estimates-impact-covid-19-global-poverty.

Suryahadi, A., Al Izzati, R. and Suryadarma, D. (2020) The Impact of COVID-19 Outbreak on Poverty: An Estimation for Indonesia. April 2020. Jakarta.

Weible, C. M. et al. (2020) 'COVID-19 and the policy sciences: initial reactions and perspectives', Policy Sciences. doi: 10.1007/s 11077-020-09381-4.

Willan, J. et al. (2020) 'Challenges for NHS hospitals during covid-19 epidemic', The BMJ, 368(March), pp. 1-2. doi: 10.1136/bmj.m1117.

Zambrano-Monserrate, M. A., Ruano, M. A. and Sanchez-Alcalde, L. (2020) 'Indirect effects of COVID-19 on the environment', Science of the Total Environment. Elsevier B.V., 728, p. 138813. doi: 10.1016/j.scitotenv.2020.138813. 